Check for updates

The BMJ, London, UK

kabbasi@bmj.com

Cite this as: BMJ 2021;373:n1404

http://dx.doi.org/10.1136/bmj.n1404

Published: 01 June 2021

\section{Covid-19: Cummings, Johnson, Hancock, and a maelstrom of avoidable harm}

\author{
A fast, forward looking public inquiry must be held now
}

\section{Kamran Abbasi executive editor}

Boris Johnson's announcement of a public inquiry into his government's handling of covid-19, followed hard on the heels of the news that his former special adviser Dominic Cummings would give evidence against him to the health and science all party select committees. ${ }^{1}$ The prime minister, it seemed, was more concerned about how Cummings might damage his reputation than the health of his electorate. Cummings promised a series of revelations damning enough to embarrass any leadership. ${ }^{2} \mathrm{He}$ didn't disappoint, and he did more than simply hold court at the hearing, where he was an oracle, a one man systematic review on every pandemic question, the all seeing Eye of Sauron.

Whether Cummings's many allegations are correct or not, the inescapable conclusion is that the disastrous manner in which the government is run is a major contributor to excess deaths in the UK, although Johnson persists with his denials. The public inquiry that was needed a year ago-and could be quick and forward looking ${ }^{3}$-is still promised for next year, but it is a matter of urgency now. ${ }^{4}$

\section{Dysfunctional}

Johnson was portrayed as incompetent and uncaring, ${ }^{5}$ a master of delay and disengagement, and distracted by girlfriend issues-initially dismissing covid-19 as a "scare story" and willing to be injected with SARS-CoV-2 live on television, then threatening to "let bodies pile high" instead of imposing a second lockdown. Matt Hancock, the secretary of state for health, was accused of lying and incompetence, somebody who had deserved to be sacked on at least 15 occasions but was being saved to be the scapegoat of any future public reckoning. ${ }^{6}$ The machinery of government decision making was described as dysfunctional, disjointed, and utterly disrespectful to the people it serves, leading to "tens of thousands" of avoidable deaths.

Johnson's government, from Cummings's depiction, had slept on the job in early 2020 when urgent action was essential. It had relied on flawed pandemic modelling, ignored real world experiences from east Asia and Italy, sought a narrow caucus of expert views and kept them confidential, prioritised the economy over health and wellbeing to the detriment of both, failed to protect vulnerable people in care homes and lied about it, ignored the potential of airborne spread, delayed mass testing and then set meaningless targets, left international borders uncontrolled, and oversaw a calamitous and costly procurement strategy for personal protective equipment.
The UK was ill prepared and had no pandemic plan, and even if it did it was a misguided plan that pursued herd immunity and was accepting of a large number of deaths. Johnson was dragged into each lockdown, particularly the first in late March 2020, and he delayed the key one in September by ignoring his own scientists and colleagues and backing cherry picked supporters of herd immunity.

None of this is news, at least to close observers. Nor does the judgment on these decisions depend on the benefit of hindsight, as Cummings claimed frequently during his testimony to justify his own hesitancy and inaction. The government was warned of the serious consequences of its decisions at the time and even in advance by outside experts, just as it is being warned today. ${ }^{7-10}$ None of this was unknown. ${ }^{11}$ The experience of countries that had previously responded to pandemics and learnt painful lessons, of people who had personal experience of those pandemics, and of countries ahead of the UK's pandemic wave was freely available to anybody with a curious mind, an internet connection, and a willingness to read and listen. ${ }^{12}$ Some of those people were on the government's advisory committees, although traditional public health, infectious disease control, and clinical expertise were lacking, and Cummings confirmed the dysfunctional way that scientific advice is channelled into political decision making. ${ }^{13}$

\section{New insights}

What is news is that Cummings admitted all this and laid bare the failure of government so spectacularly, albeit in a way to suit his own agenda. ${ }^{14}$ What is news is that a person whom many observers believe was running the government in place of the prime minister admitted to errors, self-doubt, and responsibility. What is news is that Cummings believes he saved the UK from being "fucked" by covid-19 with the aid of a whiteboard, iPhone, a few good friends, Spiderman memes, and Independence Day film references. What is news is that the people running the country inhabited a world in surreal isolation from outside and inside experts, even from other government officials and departments. What is news is that a government so obsessed with protecting the economy did so without Cummings seeing any economic pandemic modelling.

What is also news is that in the midst of his accusations of incompetence, Cummings failed to recognise the blind spots in his own world events don't necessarily replicate assumption laden modelling, to cobbling together data and enthusiasms-from the horrific realisation that real 
"hacking" solutions. From overlooking public health experts to concluding that an unelected and unaccountable "dictator" with no relevant experience should be put in charge of the pandemic response. From playing a hand in arguing for a fast track procurement system that opened up channels of cronyism and corruption, to lobbying tirelessly for a scientifically unproved system of mass testing based on lateral flow tests. From rightly championing use of new types of data to inform public health decision making but overlooking privacy and ownership issues, to championing a new Joint Biosecurity Centre whose secrecy sits in direct contrast to the openness with which he bared his soul at the hearing.

\section{Accountability}

What is news or is not news can be debated. But what is clear is that up to 150 ooo people have died earlier than they might have. ${ }^{15}$ The lives of their families and friends are damaged and destroyed. Many more people are living with long covid and sequelae of an avoidable disease. More people still are waiting for operations and living daily with effects on their quality of life of misused lockdowns and botched pandemic measures. A whole generation of young people have had a year stolen from their lives, and the effects on them are yet to fully emerge. The most disadvantaged in society are feeling the most severe economic effect of prolonged lockdowns as a result of a failure to control the pandemic. NHS staff and other frontline workers have endured 18 months of extreme work pressures, exposing themselves to high levels of risk.

How much of this maelstrom of harm was avoidable with the right leadership? The responsibility for the extent and the duration of the human and economic disaster rests squarely with the hubristic leaders running the country, Cummings included, who purged their party's ministries of politicians with experience and replaced them with unpractised Brexit loyalists. It is these very people who do not want a public inquiry to happen now, since they have prioritised personal gain and power ahead of the lives and welfare of the public. It is precisely for this reason that an inquiry must happen now. The success of the vaccination programme must not be allowed to cover for a national disaster, and nor must Cummings's testimony become a substitute for the government's public accountability.

Competing interests: I have read and understood BMJ policy on declaration of interests and have no relevant interests to declare.

Provenance and peer review: Commissioned; externally peer reviewed.

1 Cowper A. What doctors need to know about the Greensill scandal. BMJ2021;373:n1245. doi: 10.1136/bmj.n1245 pmid: 33990341

2 Cummings D. Twitter 17 May 2021. https://twitter.com/Dominic2306/status/1394245014440529921

3 McKee M, Gill M, Wollaston S. Public inquiry into UK's response to covid-19. BMJ 2020;369:m2052. doi: 10.1136/bmj.m2052 pmid: 32444349

4 Oliver D. A public covid-19 inquiry tomorrow shouldn't stop action today. BMJ 2021;373:n1377. doi: 10.1136/bmj.n1377

5 lacobucci G. Covid-19: Thousands died needlessly from UK pandemic response, says PM's former aide. BMJ2021;373:n1374. doi: 10.1136/bmj.n1374 pmid: 34045182

6 lacobucci G. Covid-19: PM's former chief aide accuses health secretary of lying over PPE and access to treatment. BMJ 2021;373:n1369. doi: 10.1136/bmj.n1369 pmid: 34039614

7 Scally G, Jacobson B, Abbasi K. The UK's public health response to covid-19. BMJ 2020;369:m1932. doi: 10.1136/bmj.m1932 pmid: 32414712

8 Carinci F. Covid-19: preparedness, decentralisation, and the hunt for patient zero. BMJ 2020;368:m799. doi: 10.1136/bmj.m799. pmid: 32111645

$9 \quad$ Watkins J. Preventing a covid-19 pandemic. BMJ2020;368:m810. doi: 10.1136/bmj.m810 pmid: 32111649

10 Gurdasani D, Pagel C, McKee M, Reicher S, Ziauddeen H. The UK's response to new variants: a story of obfuscation and chaos. BMJ Opinion, 28 May 2021. https://blogs.bmj.com/bmi/2021/05/28/the-uks-response-to-new-variants-a-story-of-obfuscationand-chaos/
11 Wenham C, Kavanagh M, Torres I, Yamey G. Preparing for the next pandemic. BMJ 2021;373:n1295. doi: 10.1136/bmj.n1295. pmid: 34020969

12 Kickbusch I, Leung GM, Bhutta ZA, Matsoso MP, Ihekweazu C, Abbasi K. Covid-19: how a virus is turning the world upside down. BM/2020;369:m1336. doi: 10.1136/bmj.m1336 pmid: 32245802

13 Middleton J. UK's alternative scientific advisers put public health first. BMJ 2020;369:m2056. doi: 10.1136/bmj.m2056 pmid: 32461323

14 Dominic Cummings claims "tens of thousands" died unnecessarily because of way Covid was handled-as it happened. Guardian 2021 May 26. https://www.theguardian.com/politics/live/2021/may/26/uk-covid-news-live-dominic-cummings-boris-johnson-covid-evidencepmqs

15 Office for National Statistics. Deaths registered weekly in England and Wales, provisional: week ending 14 May 2021.https://www.ons.gov.uk/peoplepopulationandcommunity/birthsdeathsandmarriages/deaths/bulletins/deathsregisteredweeklyinenglandandwalesprovisional/weekending14may2021

This article is made freely available for use in accordance with BMJ's website terms and conditions for the duration of the covid-19 pandemic or until otherwise determined by BMJ. You may use, download and print the article for any lawful, non-commercial purpose (including text and data mining) provided that all copyright notices and trade marks are retained. 